\title{
Strategies for Integrating Excellent Traditional Chinese Culture into College English Teaching
}

\author{
Jingwen $\mathrm{Ma}^{*}$ \\ Foreign language department, Shandong Technology and Business University, Yantai Shandong, China, 264005 \\ *Corresponding author. Email: jessie1128@163.com
}

\begin{abstract}
In the context of accelerating globalization, the integration of Chinese traditional culture into college English teaching is not only necessary for the cultivation of college students' intercultural communication ability, but also conducive to the inheritance and promotion of Chinese traditional culture among college students and the promotion of communication between China and other countries. This paper analyzes the necessity of integrating excellent traditional Chinese culture into college English teaching, points out the current situation of college English teaching and traditional Chinese culture integration from the following four aspects of "emphasizing exam-oriented education and neglecting language application, emphasizing knowledge transmission and neglecting quality development, emphasizing western culture and neglecting traditional Chinese culture, emphasizing English context and neglecting local context", and finally puts forward the strategies of integrating excellent traditional Chinese culture into college English teaching from the following several aspects of textbook compilation, teachers training, learning atmosphere, teaching methods and so on.
\end{abstract}

Keywords: Excellent traditional Chinese culture, College English teaching, Strategies.

\section{INTRODUCTION}

College English is one of the courses with long teaching time, large class amount, and most involved in foreign language learning and cross-cultural thinking. It plays a vital role in improving college students' cultural confidence. The College English Teaching Guide (2017) clearly states that in the process of English teaching, students should "understand foreign societies and cultures, enhance their understanding of different cultures, enhance their awareness of the similarities and differences between Chinese and foreign cultures, and cultivate their intercultural communication skills". With the development of cross-cultural communication, college English teachers have a great sense of intercultural communication, but for a long time most teachers just emphasize the improvement of the purpose language competence and foreign culture but have ignored the status of excellent traditional Chinese culture in teaching. The serious consequence is that most students are not familiar with the native culture English expression in the two-way cross-cultural communication, so also it is difficult to shoulder the responsibilities of spreading excellent traditional Chinese culture. Therefore, it is a new task for Chinese college English teachers to integrate the excellent traditional Chinese culture into college English teaching and realize the popularization and coverage of the excellent traditional Chinese culture in college courses.

\section{THE NECESSITY OF INTEGRATING EXCELLENT TRADITIONAL CHINESE CULTURE INTO COLLEGE ENGLISH CLASSROOM TEACHING}

\subsection{To Meet the Needs of Increasingly Close Foreign Exchanges}

In September and October 2013, Xi Jinping put forward the "One Belt and One Road" initiative during his visits to Kazakhstan and Indonesia. In this context, the strategy of "going out" of excellent traditional Chinese culture poses new challenges for the cultivation of talents in institutions of higher learning. College English teaching should not only cultivate college students' foreign language ability and teach western culture, but also shoulder the mission of inheriting and carrying forward excellent traditional Chinese culture. "Only when we understand our own culture can we better master foreign culture." General Secretary Xi 
Jinping once mentioned that China has a unique history and culture, which directly determines that China must follow its own path of higher education development. Guided by the Belt and Road initiative, in order to strengthen cultural exchanges between China and the West, $\mathrm{Xi}$ Jinping has raised the issue of "cultural confidence" on different occasions. He pointed out that "cultural confidence is a more fundamental, broader and deeper confidence" (Xi Jinping, 2016), and further pointed out in his report to the 19th National Congress that "without high cultural confidence and cultural prosperity, there will be no great rejuvenation of the Chinese nation" (Xi Jinping, 2017). Cultural confidence refers to "a country, a nation and a political party's full affirmation of its own cultural value and firm belief in its own cultural vitality" (Spruce 2010). However, due to historical reasons, domestic attention to our own culture is far from enough. What is more worrying is that college students are indifferent to Chinese culture.

Under the background of "One Belt and One Road" in the new era, how to realize the integration of patriotism and cultural character education and strengthen cultural confidence has become a major ideological and political issue for college English courses. Therefore, college English teachers must integrate the excellent traditional Chinese culture into foreign language teaching, consciously cultivate college students' identification with their own national traditional culture, improve their ability to express traditional Chinese culture in foreign languages, and then realize true intercultural communication.

\subsection{Meet the Needs of the People for Higher Education}

At present, a variety of ideas, cultures and viewpoints are exchanged, blended and fought in the world, and ideologies are diverse and varied, which all pose new challenges to the talent cultivation of universities and colleges. Guided by Xi Jinping's the ideas of socialism with Chinese characteristics in the new era, actively response to the new characteristics, new problems and new trends in the field of higher education, Colleges and universities must take the cultivation of qualified builders and reliable successors of the socialist cause with Chinese characteristics as a fundamental political task, realize the connotative development, do a good job of people's satisfaction of higher education. Guiding College students, the future successors of China to feel the great charm of Chinese traditional culture is the inherent requirement of national culture inheritance. The organic integration of college English courses into Chinese traditional culture can not only enrich the contents of the courses, but also enhance students' cultural confidence in the learning process and cultivate their feelings of family and country in the enhancement of cultural confidence. Confidence in the path, theory, system and culture is an important prerequisite for the great rejuvenation of the Chinese nation, and it is the due responsibility of college students in the new era.

\subsection{To improve College Students' Intercultural Communication Ability}

In international communication, a foreign language is not only used as a communication tool, but also undertakes the mission of communicating different cultures and spreading Chinese civilization. At present, the goal of college English teaching is to cultivate students' intercultural communication ability through the interaction of theory and practice, and to provide assistance for students' all-round development. Combined with this educational goal, the cultivation of intercultural communication competence should be divided into two parts, namely Chinese culture and English culture. However, the lack of Chinese culture in foreign language teaching in China has seriously hindered the improvement of students' intercultural communication ability, and even affected the spread of excellent Chinese culture. Therefore, traditional cultural knowledge in college English teaching, not only makes students form a comprehensive and accurate cognition of native culture, cultivate the students' humanities accomplishment, but also can use English to introduce the real China to the rest of the world, promote the contemporary college students' cross-cultural communication ability, realize the further development of language ability, and push the Chinese excellent traditional culture to the world.

\subsection{To set up Correct Values for College Students}

During college, students' mind is still immature. Therefore, students in this period are easily influenced by external factors. In college English teaching, if teachers overemphasize the language and culture knowledge of western countries and ignore the related knowledge of excellent Traditional Chinese culture, it is easy to cause students to blindly worship and blindly accept the culture of western countries, and lose their confidence and pride in their mother tongue culture. As is known to all, the fine traditional Chinese culture is extensive and profound, and it is the precious spiritual wealth accumulated over thousands of years by all ethnic groups in China. Therefore, by integrating Chinese traditional culture into college English classroom teaching, students can enhance their patriotism, improve their ability to judge foreign cultures, and constantly enhance their national self-esteem, self-confidence and pride, so as to establish correct values. 


\section{THE CHALLENGES OF INTEGRATING EXCELLENT TRADITIONAL CHINESE CULTURE INTO COLLEGE ENGLISH TEACHING}

In college education, college English is a basic course offered by every university and a basic knowledge that every college student should learn. Integrating excellent Chinese traditional culture into college English teaching can realize the popularization and coverage of excellent Chinese traditional culture in college courses. However, in the current college English teaching, there are still some challenges to integrate the excellent traditional Chinese culture into college English teaching, mainly reflected in the following aspects:

\subsection{Emphasizing "Exam-oriented Education" and neglecting "Language Application"}

At present, the most important problem in college English teaching is examination-oriented education. Schools and teachers pursue the pass rate of CET-4 and CET-6, and students study English in order to achieve ideal test scores. In class, teachers focus most of their energy on analyzing the grammatical structure and explaining a large amount of knowledge. It is difficult to integrate the excellent traditional Chinese culture into the classroom, which brings hidden dangers to students' English learning to a large extent. Some students do well in English tests with standard pronunciation and intonation and accurate grammar, but they often make "cultural mistakes" when communicating in English.

In today's college English teaching, many college English teachers only pay attention to students' practical use of English language and English learning of theoretical knowledge, but ignores the excellent traditional culture of infiltration in the English classroom, and the teaching material content of the excellent traditional culture. As a result, college English classes are mainly to teach language knowledge. However, it is not enough to impart knowledge only in college teaching, but also to integrate the connotation of quality cultivation and give full play to the hidden education function of our excellent traditional culture in English classroom.

\subsection{Emphasizing "Knowledge transmission" and neglecting "Quality Development"}

In today's college English teaching, many college English teachers only pay attention to students' practical use of English language and English learning of theoretical knowledge, but ignores the infiltrationof excellent traditional culture in the English classroom, and the teaching material content of the excellent traditional culture. As a result, college English classes are mainly to teach language knowledge. However, it is not enough to impart knowledge only in college teaching, but also to integrate the connotation of quality cultivation and give full play to the hidden education function of our excellent traditional culture in English classroom.

\subsection{Emphasizing "Western culture" and Neglecting "Chinese culture"}

Since English language originates from western countries, it is necessary to interpret English knowledge from the perspective of western culture in college English teaching, which is undoubtedly necessary for students to master English knowledge and English skills. However, if we ignore the inheritance and education of the excellent culture of our country, it will lead to the "westernization" of the curriculum and the inadequation of the education of the excellent traditional Chinese culture, which is contrary to our educational policy and the purpose of talent cultivation. In addition, English teaching materials are the main carriers of English teaching and learning, most of which focus on professional knowledge content, resulting in the lack of infiltration of excellent Chinese culture in actual English classroom teaching.

\subsection{Emphasizing "English Context" and neglecting "Local Context"}

At present, western culture occupies a large proportion in the world culture, and many countries are inevitably invaded and even assimilated by western culture. However, there are some problems in college English teaching in China, such as attaching importance to western culture while neglecting Chinese culture. College English education pay more attention to the context the use of language. The basic system and basic content, basic method of the English teaching must accelerate the spread of knowledge of English, leading to ignore the local context, reducing the understanding of the local context.This is not consistent with China's educational policy and talent training program. Therefore, it is necessary to organically integrate "local Excellent Chinese cultural context" under the condition of "English context".

\section{THE STRATEGIES OF INTEGRATING THE EXCELLENT TRADITIONAL CHINESE CULTURE INTO COLLEGE ENGLISH TEACHING}

\subsection{Compiling Textbooks Integrating Excellent Traditional Chinese Culture}

Most of the textbooks used now are original Western articles, so English articles of Chinese culture should be appropriately introduced. College English teaching 
materials are mainly imported into Western or American culture, which is a one-way input and cannot meet the needs of college English teaching. Therefore, in English teaching, English teachers should combine China's national conditions, students' abilities and social needs to constantly develop English teaching materials, so as to enrich Chinese cultural themes and enable students to understand and master the English expression of Chinese culture. It is the first and foremost key to revise English teaching materials that highlight Chinese cultural values and strengthen national cultural cognition. In the information age, the cycle of knowledge aging is getting shorter day by day, and the world pattern and language have undergone great changes. If the textbooks cannot be brought to the same level, they cannot keep up with the new target of talent training.

\subsection{The cultivation of English teachers in our excellent traditional Chinese culture}

College English teachers are disseminators of English knowledge and culture. Their understanding and mastery of traditional Chinese culture, their choice of teaching philosophy and thoughts, teaching strategies and methods of traditional Chinese culture will influence the improvement of students' traditional cultural quality to different degrees. Due to historical reasons, college English teachers do not have a comprehensive understanding of Chinese cultural knowledge, lack of accumulation of Chinese cultural vocabulary and expressions, and cannot impart Chinese cultural knowledge well, which is bound to lead to the lack of students' ability in cross-cultural communication. With the continuous development of science and technology, the society has higher and higher requirements on college students' practical English application ability, and English teachers have more and more responsibilities. In order to give full play to the dual tasks of language teaching and cultural communication, English teachers must have rich knowledge of Western culture and profound literacy of Chinese culture, so as to complete English teaching well and achieve the real teaching objectives. Therefore, English teachers should re-examine ourselves, in the teaching continuously grope for how to improve their cultural quality, how to improve their ability to express Chinese culture as well as to examine their cross-cultural communication consciousness and ability, continuously improve their own teaching as knowledge to reassure people.

\subsection{Permeate Excellent Traditional Culture in the Whole Teaching Process}

As an important channel of learning knowledge, classroom learning can not only consolidate the relevant knowledge that students have learned, but also help to improve students' awareness and ability of independent innovation. At present, our classroom communication is very limited, the key for students to study is to grasp the time outside the classroom. However, due to their relatively poor self-discipline, they often find it difficult to learn by themselves in an environment without teachers' guidance or a relatively poor learning atmosphere, or they are attracted by some tempting things. In this regard, we need to broaden the channels for students to get in touch with the cultural resources of their mother tongue, so as to strengthen the learning of the cultural knowledge of their mother tongue. For example, teachers can assign classroom assignments that involve collecting cultural resources in the student's mother tongue. Let them compare and analyze the dressing and behavior habits of people in different periods and regions, and communicate with each other in class. In addition, teachers can also provide students with English lectures or special introductions on the culture of their mother tongue, and organize a variety of cultural week and cultural month activities, so as to provide students with a good platform to show themselves, strengthen communication and learning.

Teachers can also actively promote the in-depth integration of information technology and English teaching; broaden the channels for cultivating cultural confidence. The development of information technology provides the possibility for the extension of the extracurricular activities. Active use of online teaching and mobile learning resources, such as open teaching mode, the opening of a series of Chinese culture in English courses, lectures on culture contrast, construction or the introduction of cross-cultural communication class for class will become the powerful supplement of learning English, can deepen students' ability to the understanding of the Chinese culture, promote cultural confidence.

\subsection{Incorporate Excellent Traditional Culture into Curriculum Ideology}

We should strengthen the introduction of Chinese culture by relying on curriculum ideology and politics. College English teaching should find and make good use of the "breakthrough point" of "curriculum ideology", combine the teaching themes with Chinese culture education, and combine the teaching content with the development of students' cultural consciousness, so that the teaching resources and content of Chinese culture can be skillfully integrated into classroom ideology teaching activities, and the teaching effect can be improved to the greatest extent. Along with the network popularization, more and more students access to information channels, actively guide students to focus on domestic and international news and information, make full use of network media, pay attention to the events of the world, not only to learn the 
essence of the west, also want to let the students know more about the essence of Chinese traditional culture, to the student's own development and the ability of the cross-cultural communication has an important influence.

\section{CONCLUSION}

Teaching English and learning foreign culture is not wholesale westernization, we should not forget our own culture.As early as 1991, China's famous scholars Mr Ji Xianlin had bold assertions, in the 21 st century, the western culture will gradually give way to the oriental culture with the improvement of China's economic development and international status.Many Chinese and foreign scholars have predicted that the 21 st century will be the century in which Chinese culture plays an increasingly important role, Chinese cultural Renaissance time has come. English teaching in China should make good preparations for this, strengthen the introduction of Chinese culture, guide and help English learners to understand the tradition, evolution and expression of their own national culture, improve their cross-cultural communication ability, and make them a worthy ambassador of Chinese culture. Only in this way can English teaching in China not disgrace the mission of inheriting Chinese culture and make the extensive and profound Chinese culture play its due role in the new era. English teachers in English classroom teaching exert a subtle infiltration of Chinese traditional culture education, to make the students in the daily learning inherit our excellent traditional culture, let the students master the knowledge of English and learn more Chinese culture, and truly feel double charm of traditional culture and the English subject.

\section{ACKNOWLEDGMENTS}

Fund project: Education Reform Project of Shandong Institute of Business and Technology in 2020(project number: 11688202044)

\section{REFERENCES}

[1]Qin Hui. On the strategies of integrating Chinese traditional culture into college English teaching [J]. Overseas English, 2021, (10):213-214.

[2]Jiang Ni. Reflections on the Integration of Excellent Traditional Chinese Culture into College English Teaching [J]. Journal of Qingdao Vocational and Technical College, 2021, 34(03):57-60.

[3Liu Hui. The Absence and Reconstruction of Chinese Excellent Traditional Culture in College English Teachers [J]. Journal of Shenyang Agricultural University (Social Science Edition), 2020, 22(05):605-609.

[4]Zheng Yimei. An effective way to integrate Excellent Traditional Chinese culture into College English Teaching under ideological and political background -- Taking tea culture as an example [J]. Fujian Tea, 2020, 42(08):176-177.

[5]Liu Qihon, Qin Lan. Reflections on the Integration of Chinese Excellent Traditional Culture into College English Classroom [J]. Journal of Hebei Radio and Television University, 2019, 24(06):78-80.

[6]Wei-hong Zhao, Dao-ping Xu, Hongxia Wang. A Study on the Integration of Chinese Excellent Traditional Culture and College English Teaching [J]. International Journal of Education and Economics, 2019, 2(4):

[7]Yue Hongxing. A Study on the Strategies of Integrating Chinese Excellent Traditional Culture into College English Classroom Teaching [J]. Journal of Jilin Radio and Television University, 2019, (06):10-11. 